\title{
CONTEMPORARY ISLAMIC JURISPRUDENCE THOUGH IN THE WORK OF KHALED ABOU EL FADL
}

\author{
Qurrotul Ainiyah \\ Institut Agama Islam Al Falah As Asunniyyah Kencong Jember \\ jayaaini@gmail.com
}

Abstract: With a qualitative approach, this research raises Khaled Abou El Fadl's thoughts on contemporary Islamic law discourse by analyzing one of his main works, namely Speaking in God's Name: Islamic Law, Authority, and Women. This paper will be focused on two important questions. First, how is the history of Khaled Abou El Fadl's life? Second, how is Khaled Abou El Fadl's thought style in the tradition of contemporary jurisprudence? Based on those two questions, this research finally produces that; First, Abou El Fadl grew out of the dialectic of Islamic thought in the Middle East which has grown since the 1970s. His thought was actually a reaction to the rise of Salafi discourses, especially in Saudi Arabia and Egypt. The idea of Abou El Fadl is seen as a moderate wing representation in Salafi thought. Second, Atas Nama Tuhan, Khaled Aboul El Fadl's work is an experiment of his criticism of Salafism ideology which argues that Islamic reformism is also responsible for creating a creed closed, intolerant, and superficial in understanding the sacred texts of Islam should be taken seriously. His thought provides a discourse on Islamic law by combining classical Islamic thought with modern hermeneutic discourse.

Keyword: fiqh, contemporary thought, speaking in god's name, khaled aboul el fadl

Abstrak: Dengan pendekatan kualitatif, penelitian ini mengangkat pemikiran Khaled Abou El Fadl tentang wacana hukum Islam kontemporer dengan menganalisis salah satu karya utamanya, yaitu Speaking in God's Name: Islamic Law, Authority, and Women. Makalah ini fokus 
pada dua pertanyaan penting. Pertama, bagaimana sejarah kehidupan Khaled Abou El Fadl? Kedua, bagaimana gaya berpikir Khaled Abou El Fadl dalam tradisi yurisprudensi kontemporer? Berdasarkan dua pertanyaan itu, penelitian ini akhirnya menghasilkan kesimpulan; pertama, Abou El Fadl tumbuh dari dialektika pemikiran Islam di Timur Tengah yang telah berkembang sejak tahun 1970-an. Pemikirannya sebenarnya merupakan reaksi terhadap munculnya wacana Salafi, terutama di Arab Saudi dan Mesir. Gagasan Abou El Fadl dipandang sebagai representasi sayap moderat dalam pemikiran Salafi. Kedua, Atas Nama Tuhan, karya Khaled Aboul El Fadl adalah kritiknya terhadap ideologi Salafisme yang berpendapat bahwa reformisme Islam juga bertanggung jawab untuk menciptakan kredo yang tertutup, tidak toleran, dan dangkal dalam memahami teks-teks suci Islam harus ditanggapi dengan serius. Pemikirannya berkontribusi terhadap wacana pemikiran hukum Islam baru dengan menggabungkan pemikiran Islam klasik dengan wacana hermeneutik modern.

Kata kunci : fiqh, pemikiran kontemporer, speaking in god's name, khaled aboul el fadl

\section{INTRODUCTION}

The 1970s decade was the beginning of a new phase in the history of contemporary Islamic thought and practice. Several observers who examine this phenomenon generally call it as 'Islamic resurgence' in Muslim public spaces. (Voll, 1982) The establishment of the Islamic Republic of Iran in 1979 was a typical expression of this trend. In various other parts of the Islamic world, efforts can also be made to make Islamization in various fields, ranging from practical and individual questions such as clothing and arts, to complex ones such as knowledge Islamization and.state legislation of Sharīah.

While the phenomenon of Islamic revival deserves to be welcomed as an expression of religious enthusiasm which had faded with the 'secular' ideologies 
such as nationalism, socialism and communism; this tendency is not inappropriate for criticism. For example, the Sharīah legislation which is often accused of suppressing civil liberties, human rights, or simply being a tool for the authorities to oppress political opponents. Critics also emerged that in their 'codified' or 'modernized' forms; Islamic law was increasingly closed and become authoritarian (Messick, 2003). Apostasy accusations that must be faced by Mahmud Muhammad Țaha in Sudan and Nașr āmm Abū Zayd in Egypt, simply because they offered a reinterpretation of the Qur'an or traditional fiqh doctrine which became the latest example of the arbitrariness of legal decisions in the context of Islamization (An-Na'im, 2008:95-115). Likewise, the fatwa that liberalism, pluralism and secularism are illegitimate by the Indonesian Ulama Council without giving complex attention to the meaning of the three terms. This is a symptom of authoritarian tendencies in the latest fiqh discourse (Hosein, 2004: 147-179). In the hands of extremist Muslims, Islamic law is used as a tool to justify the violence they commit. This fatwa stated by Osama bin Laden so that Muslims want to jihad against America with terror even to innocent civilians; this is an extreme manifestation of this trend (Kurzman, 2002: 3-20).

Why does contemporary Islamic legal discourse grow authoritarian tendencies in interpreting the text? What are the backgrounds? How should we deal with this tendency? One of contemporary Muslim intellectual who actively discusses and tries to provide answers to the questions above is Khaled Abou El Fadl. Professor of Islamic law at the UCLA School of Law, United States of America, is a prolific writer who actively writes about issues of Islamic thought and practice in modern times, ranging from politics, human rights, democracy, to the fiqh and ushul figh traditions. Because of his efforts in reinterpreting the Qur'an and Hadith; or adjusting the teachings of Sharīah in the present context, Abou El Fadl can be juxtaposed with other contemporary Muslim intellectuals who have similar intellectual concerns, such as Abdol karim Soroush, Nașr Ḥāmid Abū Zayd, Abdullahi Ahmed An-Na'im to Muhammad Shahrur (Karim, 2000). 
This paper intends to explore Abou El Fadl's main ideas about contemporary Islamic law discourse by analyzing one of his main works, Speaking in God's Name: Islamic Law, Authority, and Women. To provide the context for this discussion, the first discussion of this paper directed to present a biographical sketch of Abou El Fadl (Yasin, 2004).

\section{METHOD}

This study uses a qualitative approach with library research. The researcher raised Abou El Fadl's main ideas about contemporary Islamic law discourse by analyzing one of his main works, Speaking in God's Name: Islamic Law, Authority, and Women. This study uses analytical and historical content to examine the work of Abou El Fadl who approaches and criticizes the tradition of contemporary Islamic law as insider. Abou El Fadl Thought in Speaking in God's Name: Islamic Law, Authority, and Women will described as codes and themes, researchers can use the code at the top, "description of theory and visual model", to create visuals of processes related to code this (Creswell, 2018: 254).

\section{BIOGRAPHICAL AND IDEAS}

Khaled Abou El Fadl was born in Kuwait in 1963. He was from an Egyptian expatriate family who has lived in this oil country since the 1950s (Barrett, 2008). His father, Medhat Abou El Fadl was an Egyptian lawyer who was active in social work. In Kuwait, he assisted to establish a mental hospital, which was announced by President Gamal Abdel Nasser as a part of his pan-Arabism project. He also persistently and naively believed in the importance of democracy and freedom for the development of his country and actively campaigned for both. The problem is in Egypt when still dominated by Nasserism, these activity can be interpreted as subversion. Given by these, the secret police can intervenced and arrest and exiled to Kuwait (Marsot, 2007: 127-155). Afterwards, he met and married with Afaf El 
Nimr in Kuwait. The couple has three children and as an Egyptian family in exile, they were "constantly waiting, waiting to be returned to Egypt," remembered Abou El Fadl (Barrett, 2008: 99).

In Kuwait, young Khaled grew up in the atmosphere of the Arab World in the 1960s when Nasserism began to fail and Arab countries embarrassingly lost the war against Israel in 1967. In this atmosphere, utopian dreams like those offered by political Islam began to fascinate the youth, including Khaled. According to these zealous youth, "only the people who hold to the Qur'an as their constitution will be able to defeat the Zionists, overthrow the Arab tyrants, and be able to avoid or escape the influence of American and Soviet secularization" (Barrett, 2008: 100). As he remembered later, Khaled, like the other youths who were burned by the spirit of political Islam, began to grow beards and used siwak wood to brush his teeth. He also destroyed his sister's Rod Stewart tapes and laughed at his father's conviction that elections and freedom of expression would strengthen Arab society.

His father decided to send Khaled to a traditional Islamic education institution that had not been touched by Islamism. He studied traditional Islamic sciences such as Nahwu, Sarraf, Logic, Figh, Ushul Figh, Tafsir, and Hadith. Khaled woke up from his utopian dream and hoped he could continue his studies at the oldest Islamic university in his native land: al-Azhar. The problem is that Abou El Fadl's family is an exile family that is impossible to be accepted in Egypt, even after a regime change. Khaled's arrival in his hometown was very likely to provoke the arrival of secret police. Moreover, he had begun writing and publishing a number of writings that criticized the Egyptian government in Kuwait.

A family friend who once served as a minister in Egypt advised Khaled to abandon his plans to study Islamic law in Egypt. He advised him to enroll in college at Yale University, United States. Unexpectedly, Abou El Fadl successfully passed. A telegram arrived from New Haven, Connecticut, which told Khaled that he was accepted as a first-year student. In 1982, at the age of eighteen, he went to the 
United States to study there. His achievements at Yale University were very rapid. This immigrant student at the Beinecke Library received the Scholar of the House, one of Yale University's undergraduate academic honors in the spring of his junior year.

After studying at Yale University, Abou El Fadl was determined to return to Egypt and study at al-Azhar, Cairo. He finally studied about Figh and Ushul Figh there. At the al-Azhar, Abou El Fadl recognized the issues and the discourse of progressive Islam which was proclaimed by the prominent shaikh of al-Azhar, such as Muhammad al-Ghazālī and Abd al-alīm Maḥmūd. Al-Azhar scholars inherited the centuries-old traditionalism on the one hand and thought reformism as offered by Jamāluddin al-Afghānī (1839-1897) and Muhammad Abduh (1849$1905)$ on the other side. The second teaching, usually called Salafism, invites Muslims to return to the precedent of the al-salaf al-șālih, so that they can rediscover the practice of authentic Islam and escape from the shackles of taklid. They also encourage Muslims to be more open to the latest developments in the scientific tradition and Western philosophy and to use them for the advancement of Islam (Hourani, 1983: 103-160).

Abduh's students and heirs of thought divided into two main thoughts in interpreting their teacher's main ideas (Hourani, 1983:163). The first continues the puritan tendencies in his thinking. The main representatives of this group are Muhammad Rashid Riḍa (1865-1935) (Soage, 2008: 1-23). While the others develop further about the modernist side of his thought. The most important representatives of this tendency were Qasim Amin (1865-1908), Ahmad Lutfi alSayyid (1872-1963), and îAli 'Abd al-Rāziq (1888-1966).

Meanwhile in Hijāz, far from the hustle and bustle of contact with the West, there was an entirely different movement, but it would also color and complicate the Salafism Afghānī and bdAbduh: the Wahhābī movement which was pioneered by Muhammad ibn Abd al-Wahhā (1703-1791). These followers of Ahmad ibn Hanbal and Ibn Taymiyyah (1263-1328) were concerned about the religious 
tendencies of the Muslims which he thought had been far deviated from the tradition of al-salaf al-șālih. He strongly condemned kalām intellectualism or philosophy; Sufism practices; and sectarianism which he accused of being heretical like Shīah. Alternatively, he offered the rigid literalism in reading the Qur'an and hadīth (Haj, 2009: 30-66). Ibn "Abd al-Wahhāb worked with Abd al'Azīz ibn Sa'ūd, a tribal leader from Najd to spread his teachings. Their cooperation paid off. In 1924, they established the Saudi Dynasty and the Wahhābi doctrine became the official teaching of the state. Since the 1970s, with the oil 'boombing', the Sa'ūdi government increasingly actively preached the Wahhābi doctrine throughout the world with the help of abundant funds from oil prices.

The response of the Azhari clerics to Wahhabism was quite complex. Rashīd Riḍā, Abduh's puritan successor, called Ibn Abd al-Wahhāb as a reformer of the 12th century of Hijrah. He welcomed the Wahhābī's victory in Najd as "a longawaited new era in Islam" because they were fighting against three "dangers" which were threatening "Islamic unity from within and might be supported by foreign powers": "fanatical Shīah group, "The Sufis he called" grave worshipers, "and" atheists from the West" (Soage, 2008: 10-11). In contrast, moderate reformers represented by Abd al-Ḥalīm Maḥmūd and Maḥmūd Shaltūt tried to offer alternative discourses that valued mazhabi traditionalism, Sufism and tried to bridge the Sunni-Shīah conflict (Hatina, 2007: 138-157).

Muhammad al-Ghazālī one of al-Azhar's moderate Ulama respected by Abou El Fadl and might influence his methodology in interpreting the Qur'an or in contact with the Hadith literature. In 1989, he wrote a book which was then sharply criticized by conservative scholars, al-Sunnah al-Nabawiyyah bayna Ahl alFigh wa Ahl al-thadith. He was not satisfied with the traditional approach in dalam hadith criticism, so far he values too oriented to the criticism of the sanad or its transmission path. He asked the scholars to be more critical of the hadith literature and consider the use of matan criticism or Hadit texts (al-Ghazali: 1989). He was also a strong critic of Wahhabism. On one occasion, he stated that the 
Wahhābī resurrection was a representation of the rise of shallow and uneducated interpretation of the Bedouins ( Abou El Fadl, 2004: 88-94).

While studying at al-Azhar, he always bowed his face and hoped that the police had more important targets than him to be disturbs. Before deciding to study in Cairo, he actually tried twice to visit Egypt. The result showed that he was arrested and beaten by the secret police. The traumatic experience scared him. "I am just sitting and my heart is beating so hard every time I hear footsteps, especially after midnight, because they always come after midnight," (Barrett, 2008: 101). His anxiety was proven, one night, when he left his halakah in Cairo, several plainclothes men arrested him, brutally mistreated him, and detained him for up to three weeks.

He completed his study at Yale and continued his law study at the University of Pennsylvania and finally earned a Ph.D. at Princeton University. The dissertation he wrote at Princeton, concerning rebellion and political resistance in the classical fiqh tradition (Abou El Fadl, 2001), contains a commentary on the discourse of the classical jurists on this theme. The hallmark of this book, which emphasizes the complexity and pluralism of the thinking of classical jurists, as well as its socio-political context, will be the main characteristic of Abou El Fadl's writings in the following periods.

His complex and unique learning experience proved to be very useful. Through his rich learning experience: On the one hand was the traditional Muslim intellectual methodology and on the other hand was the discourse of modern Western thought, Abou El Fadl can provide a unique and sophisticated perspective on sensitive themes in Islamic thought. He invited Muslims to break away from the East and West dichotomy. In an interview, he stated, "The thinking of Muslims over the past few centuries has been on pro or cons-Western issues rather than focusing on more important questions: are the thoughts of Muslims currently proor cons-human? Is the doctrinal statement of Islam currently humane or not?"(Marwah, 2018). 
Like Muhammad al-Ghazālī, Abou El Fadl was very active in promoting moderate and progressive Islam campaign, condemning terrorism and violent theology. He explicitly called the Wahhābī doctrine as the reason for the emergence of the violence and terrorism ideology. According to Abou El Fadl, their teaching was Salafism in its version which has declined because it does not respect the history, intellectualism, and is only power oriented (Abou El Fadl, 2001: 221). He invited Muslims to see religious thought as an open and plural discourse; and do not see religious tradition as something that must be taken for granted.

Another theme that became his intellectual concern was the issue of minority fiqh. As a newly growing religious group in America and Europe, Muslims must live in a Christian environment that is often suspicious and hostile. The doctrine of Islam in America and Europe is generally poorly understood by the people and its religious practices are also often not supported by social, economic, or cultural structures on the two continents. This atmosphere requires Muslims to be flexible without having to fear that this attitude is contrary to precedents in the past (Abou El Fadl, 1994: 141-187) Various Western social and political institutions, such as democracy and human rights, do not view threats to the social and political system of Islam. The flexible interpretation of the texts of the Quran and Hadith results in the conclusion that Islam teaches people to conduct deliberations, respect individual rights, and create justice. Islam does not determine a particular political system that they must follow rigidly to Muslims (Abou El Fadl, 2003).

Because of the characteristics of Islamic thought that tried to penetrate the cultural barriers between East and West, it was not surprising that Abou El Fadl often provoked strong reactions from his opponents. The Salafis accused him of being westernized; while Western writers accused him of being "hidden Islamist." In an article he wrote for the Middle East Quarterly, Daniel Pipes wrote that the anti-Wahhabi attitude shown by Abou El Fadl could not cover up hidden Islamist tendencies. For Pipes, because Abou El Fadl saw Sharīah as an inseparable part of 
Islam, he would certainly support slavery, the law of apostasy, and oppression of women(Pipes, 2004).

\section{THE SUBSTANCE AND THE TRUTH VALUE OF AUTHORITARIANISM}

According to his book entitled "Speaking In God's Name: Islamic Law, Authority And Women", Abou al-Fadl defined the word authoritarianism in terms of etymology comes from the word authority which means influence, power, and prestige. Abou al-Fadl defined authority by placing an ability to make other people to do or not to do according to those who have the authority (Abou El Fadl, 2004: 142). The meaning of authority is quite difficult to explain as it contains the ambiguity and the complexity in the aplication in various kinds of social activities (Carter, 1985: 1-3). Abou al-Fadl also distinguished between "being in authority" and "being an authority." "Being in authority" means occupying some structural positions that empower a person to comply. While "being an authority" is the position which is obtained because of the capability and electability of a person which then makes other people to receive it (Abou El Fadl, 2004: 37-38).

Another definition of "being in authority" is a coersive authority which means a person who has a structural position and is obeyed by others because of his coersive power. While "being an authority" involves the element of trust, and any behaviour consistent with justifying the trust, including the offering of persuasive arguments, will preserve or bolster such an authority (Abou El Fadl, 2004: 42-43). This is in line with Carter (1958) that the persuasive authority is authoritative but not absolute, as there is another person who has capability and electability provides services to others who hope for their skills (Carter, 1985: 2). Using the theory of persuasive authority, Abou al-Fadl tried to construct the idea of authority in Islam, by paying attention to the following: competence, determination, and agency.

In terms of terminology, Abou al-Fadl stated that authoritarianism is "the act of giving meaning to God's willing and Text accordingly and presenting the Text 
as definite, absolute, and decisive" (Abou El Fadl, 2004: 50). It is signed by the unified of the reader and the text, or the determination of the reader will become the exclusive embodiment of the text. The risk is that the text and the construction of the reader will become one and the same. And that the readers will only produce an authority interpretation, and even farther, the reader will assume that the interpretation has a competency with the original text.

In such situation, in the reality of ontology, God is the driver of authoritativeness, and the person in authority has taken God's will by playing a role as God's representative. At the ends, the construction of the person in authority and the text will become one and the same. Interpretation that leads to authoritarianism is marked by the absolute determination of meaning cannot change, in contrast to the determination of meaning that there is a dialectical process in it that will never be final.

In short, the authoritative itself has thought that it has represented the meaning of God's will. In this context, Abou al-Fadl refers to authoritarian attitudes as "robbing the God's will." Mun'im Sirry signaled that this attitude would close the the door of ijtihad in establishing Islamic law. In other words, the interpreter has placed himself as the mouthpiece of God (Sirry, 2015). Whereas Zuhairi Misrawi positioned authoritarianism as an act of locking the will of God, in a certain static setting, and presenting that opinion as something that is sure, absolute, and decisive (Miswari \& Abou El Fadl, 2015).

\section{DISSECTING AUTHORITARIAN DISCOURSE IN CONTEMPORARY}

Abou El Fadl wrote on Atas Nama Tuhan with an analytical and normative approach. He intended to draw near and criticize the legal tradition of contemporary Islam as insider (Abou El Fadl, 2004: 19). He wanted to criticize authoritarian tendencies in the discourse of contemporary Islamic law. Actually, he had written the ideas in this book in a shorter format in a book that he named 
"And God Knows the Soldiers"(Abdullah, 2003). In the book of Atas Nama Tuhan, the conceptual framework expanded and the analysis is increasingly sharp.

According to Abou El Fadl, the emergence of authoritarian tendencies in the discourse of contemporary Islamic law is due to the waning of the classical Islamic legal tradition that is open and respects pluralism of thought. He opened an introduction of Atas Nama Tuhan with a provocative statement:

"I am worried that the remains of the treasures of classical Islamic law are on the verge of extinction today. Furthermore, in my opinion, one of the most striking manifestations of this sadness is the widespread prevalence of authoritarianism in contemporary Islamic legal discourse. There is no more epistemology and normative premises that lead to the development of the classical Islamic legal tradition nowadays. In fact, the classical Islamic legal tradition upholds the premises of the establishment of consauthoritarian law; such premises are no longer enforced in the Islamic legal tradition lately" (Abou El Fadl, 2004: 1).

The tradition of classical Islamic law is a scientific tradition in charge of Fiqh, a discipline that studies the laws of God or Shari'ah as conveyed by the sacred texts in Islam: the Qur'an and Hadīth. The jurists are those who form, present, and present these laws to Muslims. Socio-historically, they are holders of authoritative legitimacy throughout Islamic history in the view of Abou El Fadl. The jurists are the owners of textual legitimacy in Islam: "Their legitimacy is based on the ability to read, understand, and interpret God's will revealed in the text which is seen as the realization of God's will" (Abou El Fadl, 2004: 28). However, the legitimacy of these jurists is not without limits. Islam does not recognize the church system, the teaching that a person or group of individuals bears the authority of God. So, Islam will not be able to accept the idea that the meaning of authoritative texts is in the hands of an exclusive group. Egalitarianism Islam emphasizes openness of access to God's truth for all people. 
Ushul fiqh is built on a number of complex epistemological premises, which aim to limit and distinguish between the textual authority of the Qur'an and Hadīs and the understanding of the jurists on both. Classical scholars usually express the difference between the scriptures and human interpretations of the passage in the dichotomy between Sharīah and fiqh. The first is God's revelation itself; while the latter is human understanding of the revelation.( Al-Shīrāzī, 1985: 6) Because the law of God was revealed to Prophet Muhammad in the form of text, human beings can find a marker (dilālah) of the 'purpose' of God behind the text. In usulfikih epistemology, there is a complicated relationship between God as the creator of the sign system (dāll), the text of the Scriptures as a system of signifiers (dalīl), and humans as signatories (mustadill).( Al-Shīrāzī, 1985: 5) Humans must rely on ra'y or its ratio in trying to find God's law (istidlāl) in the passage. Although, in the essence of the 'intention' of God in the text of the Scriptures is absolute, interpretation and human understanding of the text of the Scriptures are relative. Usulfikih revealed this principle in the rule: Kullu mujtahid mușīb, "Every mujtahid is true [in ijtihad]."

Borrowing the latest hermeneutic terminology as explained by Gadamer or Eco, Abou El Fadl explains the correlation between these concepts as "the dynamics between the author (author), text (text), and reader (reader)" (Abou El Fadl, 2004: 182) in determining the meaning. In recent hermeneutics, there is an interesting debate about what / who must determine meaning in an interpretation. There are three possible answers to this problem. The first is the meaning determined by the author or at least by an effort to understand the intent of the author (author's intention). In this first theory, it is assumed that the author of a text has formulated its meaning with the text he built, and the reader must understand the intent of the author or at least try to understand it. in line with the expression E.D. Hirsch, "Verbal meaning is something that someone wants to convey with a series of certain language symbols and that will can be accommodated by those language symbols." (Abou El Fadl, 2004: 183) 
The second possibility is centered on the role of text in determining the meaning and recognition of the autonomy of the text in determining meaning. In this theory, it is believed that texts that have a complex system of language meanings are the only way to claim authority to determine meaning. Umberto Eco said that the text has its own reality and integrity in such a way that readers must respect it and may not use the text freely without limits (Abou El Fadl, 2004: 184).

The last possibility is to give authority to determine meaning to the reader. All readers bring their subjectivity into the reading process. They project that subjectivity to the author's goals and the text. Historical context and reality influence and even shape the reader's understanding of the text (Abou El Fadl, 2004: 185). Likewise, Hans-Georg Gadamer emphasizes that the meaning is the appropriation or use of the text by the reader, not an attempt to reveal the author's intent.

If this theoretical design is projected into the debate about the process of Qur'an interpretation, where the God is positioned as 'author', the Qur'ān as 'text', and mujtahid as 'reader', the interpretations are usually centered on efforts to reveal the author's intentions because God determines all the meanings in the Qur'an. Abou El Fadl did not reject this idea, but he emphasized that the Qur'ān verses have no any significance in the efforts of humans to understand it. The problem is whether humans will be able to find it or that the historical context and background can help the exegete to find the 'purpose' of God. In the phrase Abou El Fadl:

"In the Islamic context, legal texts are a variety of clues that lead to God's Will. However, the text itself does not contain the Will of God ... Language is an imperfect human medium. Even though God uses the media in a perfect way, the media itself is not perfect. Claiming that a language can accommodate the nobleness of God's purpose, I believe, is contrary to God's majesty and His Immortality.

I am not claiming that the search for the Divine Will must be ignored. I declare that the text does not represent the entire Will of God and also the 
author. The text embodies the instructions of the Divine Will and also the will of the author" (Abou El Fadl, 2004: 194-195).

Apart from the issue whether the above hermeneutic theoretical design can be applied in the process of interpreting the Qur'an or not, it is certain that classical Islamic law theory understands the complexity of the meaning of the text and makes it as a Ushul Figh epistemological basis. As a result, classical Islamic law refuses any attempt to carry out codification and uniformity. Interpretation of Islamic texts is seen as an intellectual endeavor that will continue to be open to anyone and no one can claim that his interpretation is the most correct and authoritative compared to other interpretations. The Islamic law methodology has from the outset an open character and cons-otoritarianism. The existence of schools of law differs in doctrine and approach to Islamic law, such as the schools of Hanafī, Mālikī, Shāfi'ī, and Hanbalī are evidence of this openness tradition. According to Abou El Fadl, precisely this tradition began to collapse in a contemporary period. Puritans in particular, who condemned traditionalism as the cause of Islam's "decline" and wanted to "return" to the Qur'an and were accused of having reduced ijtihad as an attempt to "produce new rules" regardless of the complexity of the process of meaning and epistemological premise as formulated by classical fiqh (Abou El Fadl, 2004: 248). As a result, the distinction between the author and the text reader; or between Sharīah and fiqh are fading away. Abou El Fadl called this tendency 'authoritarianism in the determination of meaning'. In this case, it means taking over the will of God by those who act as 'representatives of God' so that the representative effectively then acts on his own behalf: "In the movement of an authoritarian figure, the difference between representatives and masters becomes vague and vague. The statement of a representative and the Will of the Lord become one and the same, because a representative grafts his determination into the command of his Lord" (Abou El Fadl, 2004: 205). 
The fatwa issued by al-Lajnah al-Dā'imah li'I-Buhūth al-IIImiyyah wa al-Iftā 'or the Council for Scientific Research and Legal Opinions (CRLO), the official institution in Saudi Arabia which has the authority to issue fatwas, was specifically chosen by Abou El Fadl as a representation of this trend (Abou El Fadl, 2004: 384425). According to Abou El Fadl, Ulama which join in that institution are Wahhābī. This jurists who rely on a 'somewhat selfish' premise: that since the time of alkhulafā 'al-rāshidūn, Muslims have largely failed in carrying out the God's will, and it is only in this modern times, we can improve it if we want to return to the truth and purity of Islam (Abou El Fadl, 2004: 254). In the view of Abou El Fadl, their slogan to "return to the Qur'an and Hadīth" was actually naive, ahistorical, and impossible to realize. As a result, the Wahhābī scholars only picked up the Islamic tradition "selectively, systematically, and opportunistically" (Abou El Fadl, 2004: 255). The way to return to tradition as they claim is not planned, directed, or patterned clearly. As a result, the verses of the Qur'an or Hadith are often cited haphazardly to support the establishment of puritans they adhere to who do not care about the problem of authenticity, epistemological criticism, or interpretation procedures described by classical Islamic legal theory.

CRLO fatwas, especially those relating to women's questions, show explicitly 'selective', 'unsystematic', and 'opportunistic' collection. The fatwas dealt with various issues related to women, ranging from daily questions such as about wearing a bra, opening a hijab, and photographs; about marriage and conjugal relations; to theological questions such as the creation of women and residents of hell. The answers of CRLO members' mufti to these questions are generally simple, superficial, ambiguous, and most importantly misogynistic. For example, the question of whether women are allowed to wear a bra or not, Shaykh Jibrin, one of the CRLO members, replied that if the bra is for health purposes it is permissible, but if the purpose is to deceive and tempt men then the law is haram. When a woman told CRLO scholars that she regularly visited her husband because of his great love for him; then, they responded that the practice 
was unlawful because it would cause slander and quote the Hadith attributed to the Prophet: "May Allah cursed the woman who made the grave pilgrimage." Regarding the question which is more important: getting married or higher education for women, the CRLO fatwa is firm too: Getting married is more important. "If religion and the nature of a man look pleasing to you, then marry him!" In fact, the notion of the importance of education for women is not, according to this CRLO cleric - is a thought that needs to be criticized.

Abou El Fadl did not hide his anger at this misogynistic tendency in the Wahhābī jurisprudence. He wrote:

"The most obvious characteristic of the law that removes women from public life is seen in the form of a very large reliance on the idea of slander. In these conditions, women are always seen as a piece of slander that runs and breathes. We find it difficult to find a fatwa about women without including some discussion regarding the attractiveness of women ... women may worship in mosques only if they do not cause slander; women may listen to a man recite the Qur'an or teach only if they do not cause slander; women may go to the market only if they do not cause defamation; women may not visit the tomb because it is feared to cause slander ... It seems that the law experts make a determination that slander always accompanies women in all their deeds and wherever they go. They do not realize that this is not a natural feature of women, but is a sexual projection of men" (Abou El Fadl, 2004: 347-348).

For him, this obsessive attitude towards women indicates the view that women are nothing but objects of male consumption that only deserve to be judged according to their physical form. This is a very serious form of moral violation: "By looking at women as the manifestation of sexual attraction, these law experts actually do not carry the norms of modesty, but carry immoral norms" (Abou El Fadl, 2004: 348).

According to Abou El Fadl, authoritarian figh discourse as shown by CRLO is a case of the author's use of authority by the reader to justify his own 
interpretation of the text. By doing this, puritan jurists did wrong because they identified their understanding with God's purpose. This is in line with the submission of Abou El Fadl: "By claiming that the only relevant consideration is the Will of the Author, the reader can replace the Author and position himself as the only authoritative voice. In essence, the reader has become God" (Abou El Fadl, 2004: 373).

\section{CONCLUSION}

In God's Name is an interesting experiment criticizing the discourse of Islamic law by a contemporary progressive intellectual. Khaled Aboul El Fadl succeeded in his efforts to combine the wealth of treasures of classical Islamic thought with modern hermeneutic discourse. This book marks the rise of attention to the materials of classical Islamic learning which in modern discourses are usually underestimated, accused of being rigid, or considered to be one of the causes of Islamic decline - as an alternative discourse that is open, plural, and antiauthoritarianism. His criticism of the Salafism ideology which argues that Islamic reformism is also responsible for creating a closed, intolerant, and superficial creed in understanding the sacred texts of Islam should be taken seriously.

Another feature of Abou El Fadl's thought, especially relating to women's issues, is the emphasis on the importance of morality in dealing with the legal themes. The loss of morality as one of the perspectives in the discussion of law results in outrageous formalism and legalism in the practice of contemporary Islamic law, especially in the discourse of Islamists. This is most responsible for creating authoritarian discourse in contemporary Islamic law. For these reasons, the thought of Khaled Abou El Fadl deserves to be appreciated as a critical and thought-provoking discourse.

However, the thoughts of Abou El Fadl does not mean that it should not be criticized. As shown in the discussion above, Abou El Fadl's thoughts grew out of the dialectic of Islamic thought in the Middle East that has grown since the 1970s. 
His thoughts were a reaction to the rise of Salafi discourses, especially in Saudi Arabia and Egypt. The reaction can even be said to be loud and emotional. But, it does not mean that Abou El Fadl's ideas are anti-thesis or completely break away from the Salafi discourse. It is more appropriate to place Abou El Fadl in the context of internal disputes in the Salafi discourse. Together with Muhammad alGhazāli, as his mentor, Abou El Fadl can be seen as a representation of the moderate group in Salafi thought. He tried to balance his reaction to modern Western thought on the one hand and towards turāth or the inheritance of classical Islamic thought on the other.

In summary, it is needed to conduct more research regarding to Khaled Abou al-Fadl's book entitled "Speaking In God's Name: Islamic Law, Authority And Women." By conducting more research in this interesting field of study, it will give a significant contributions to the understanding of contemprary figh tradition as a whole and in an integrated way. In addition, Abou al-Fadl's criticism of Salafism ideology has given opportunities for mouslem intellectuals to re-examine the meaning of the sacred texts which were considered as taboo and closed. Moreover, this paper is not enough to fulfill the expectation.

\section{REFERENCE}

Abou El Fadl, Khaled. 2004. Atas Nama Tuhan: Dari Fikih Otoriter ke Fikih Otoritatif, terjemahan R. Cecep Lukman Yasin. Jakarta: Serambi. 2005. The Great Theft: Wrestling Islam from the Extremists. New York: Harper Collins.

. "Islam and the Challenge of Democracy," Boston Review, April-Mei 2003. URL = <http://bostonreview.net/BR28.2/abou.html/>.

. "Islam and the Theology of Terror," Middle East Report, 221 (2001). URL = <http://www.merip.org/mer/mer221/islam-theology-power $/>$. 
. 1994. "Islamic Law and Muslim Minorities: The Juristic Discourse on Muslim Minorities from the Second/Eight to the Eleventh/Seventeenth Centuries," Islamic Law and Society, Vol. 1, No. 2, 141-187. . 2003. Melawan "Tentara Tuhan": Yang Berwenang dan Yang Sewenangwenang dalam Wacana Islam, terjemahan Kurniawan Abdullah. Jakarta: Serambi.

. 2002. Musyawarah Buku: Menyusuri Keindahan Islam dari Kitab ke Kitab, terjemahan Abdullah Ali. Jakarta: Serambi.

2002 "The Orphans of Modernity and the Clash of Civilisations," Global Dialogue, Vol. 4, No. 2, 1-16.

. 2001. Rebellion and Violence in Islamic Law. Cambridge: Cambridge University Press.

Abū Zayd, Nașr Ḥāmid. 1996. Al-Imām al-Shāfi'ī wa Ta'sīs al-Aydīlūjiyya alWasațiyyah. Kairo: Maktabah Madbūlī.

Barrett, Paul M. 2008. American Islam: Upaya ke Arah Esensi Sebuah Agama. Jakarta: Lentera.

Brown, Daniel W. 1996. Rethinking Tradition in Modern Islamic Thought. Cambridge: Cambridge University Press.

Carter, April. 1985. Otoritas dan Demokrasi, terj. Shat Simamora. Jakarta: CV. Rajawali.

Creswell, John W. 2018. Penelitian Kualitatif dan Desain Riset: memilih di antara lima pendekatan. Yogyakarta: Pustaka Pelajar.

Fischer, Michael M.J. 2003. Iran: From Religious Dispute to Revolution. Madison: The University of Wisconsin Press.

Al-Ghazālī, Muhammad. 1989. Al-Sunnah al-Nabawiyyah bayna Ahl al-Fiqh wa Ahl al-Hadīth. Beirut: Dār al-Shurūq.

Haj, Samira. 2009. Reconfiguring Islamic Tradition: Reform, Rationality, and Modernity. Stanford, Calif.: Stanford University Press. 
Hatina, Meir. 2007. Identity Politics in the Middle East: Liberal Thought and Islamic Challenge in Egypt. London: I.B. Tauris.

Hirschkind, Charles. 1996. "Heresy or Hermeneutics? The Case of Nasr Hamid Abu Zayd," Stanford Humanities Review, 5 , 35-48.

Hosen, Nadirsyah. 2004. "Behind the Scenes: Fatwas of Majelis Ulama Indonesia (1975-1998)," Journal of Islamic Studies, Vol. 15, No. 2, 147-179.

Hourani, Albert. 1983. Arabic Thought in the Liberal Age, 1798-1939. Cambridge: Cambridge University Press.

Kurzman, Charles. 2002. "Bin Laden and Other Thoroughly Modern Muslims," Contexts (Fall/Winter), 13-20.

Lawrence, Bruce B. 2011. "The Late Shaikh Osama bin Laden: A Religious Profile of al-Qaeda's Deceased Poster Child," The Muslim World, 101, 374-389.

Marsot, Afaf Lutfi al-Sayyid. 2007. A History of Egypt from the Arab Conquest to the Present. Cambridge: Cambridge University Press.

Marwah, Hasan Basri. "Khaled Abou El Fadl; Fikih Otoritatif untuk Kemanusiaan," <http://gazali.wordpress.com/2008/01/01/khaled-abou-el-fadl-fikihotoritatif-untuk-kemanusiaan/>.

Messick, Brinkley. 1993. The Calligraphic State: Textual Domination and History in a Muslim Society. Berkeley: University of California Press.

An-Na'im, Abdullahi Ahmed. 2008. Islam and the Secular State: Negotiating the Future of Shari'a. Cambridge, Mass.: Harvard University Press. . 1986. "The Islamic Law of Apostasy and Its Modern Applicability: A Case from the Sudan," Religion, 16, 197-224.

Olsson, Susanne. 2008. "Apostasy in Egypt: Contemporary Cases of Hisba," The Muslim World, 98, 95-115.

Al-Shīrāzī, Abū Isḥāq. 1985. Al-Luma' fí Ușūl al-Fiqh. Beirut: Dār al-Kutub al'Ilmiyyah.

Sirry, Mun'im. 2015. Islam, teks terbuka dan pluralisme: Intepretasi atas Intepretasi Khaled Abou Fadl, Perspektif Progresif, Juli- Agustus. 
Soage, Ana Belén. 2008. "Rashīd Ridā's Legacy," The Muslim World, 98, 1-23.

Voll, John O. 1982. Islam: Continuity and Change in the Modern World. Boulder, Colo.: Westview Press

Zebiri, Kate. 1991. "Shaykh Maḥmūd Shaltūt: Between Tradition and Modernity," Journal of Islamic Studies, Vol. 2, No. 2, 210-224. 